\title{
Altitude Testing of Large Liquid Propellant Engines
}

\author{
For \\ The 26th AIAA Aerodynamic Measurement \\ Technology and Ground Testing Conference \\ Development of Test Facilities Session
}

\section{Presenters}

Nickey Raines and Bryon Maynard 


\section{New Exploration Objectives}

- Provided by J2-X Program Elements at MSFC

- Re-analyze Altitude Capability for J2-X

- RPTMB provided further guidance in AR 2006-MB-0351-1 in Feb 2006 for A1-b concept

- Low Cost/Low Risk Alternative to Altitude Testing

- Exploits Existing/Proven Commercially Available Industrial Systems

- Exploits Existing/Proven Design and Analysis Expertise (JE and SSC)

- Exploits Existing/Proven A-1 Test Facility Infrastructure

- Propellant Run Systems

- Propellant Storage and Transfer Systems

- Data Acquisition, Control, and Instrumentation Systems

- Structures

- TMS

- Engine Specific Systems, Interfaces, Avionics, Assembly, and Maintenance

- Exploits Existing/Proven (and Recent) SSC Test Team Experience

- Experience Testing Complex LOX/LH2 Engines

$$
\text { (e.g., SSME, RS-68, Aerospike) }
$$

- Diffuser Test Operations Experience

- Design Modularity Enables Optimization/Tailoring to

Test Requirements and Program Resources

- Enables Anytime/Interference-Free Testing

- Enables Synergistic Sea-Level and Altitude

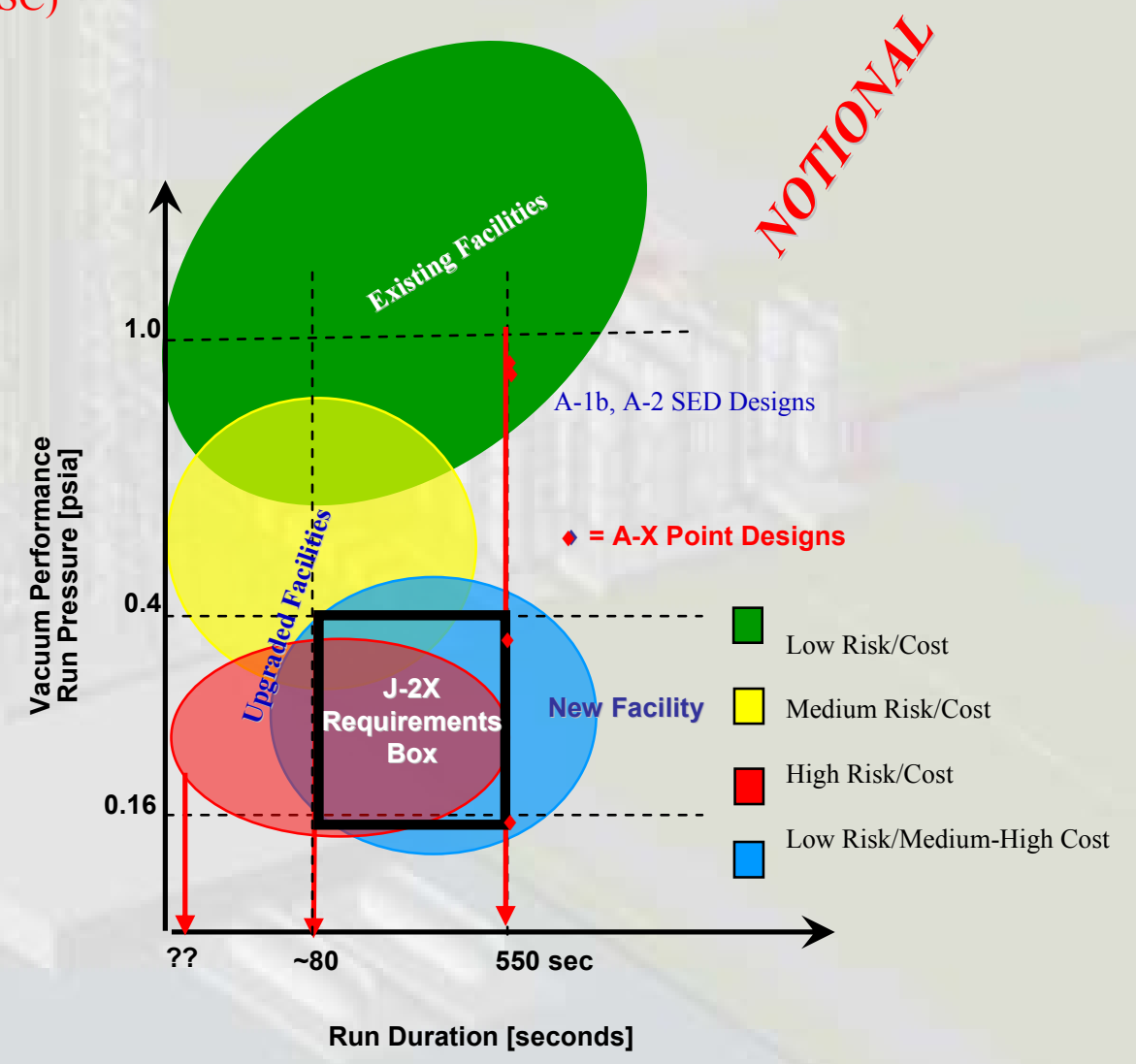




\section{A3 Test Stand}

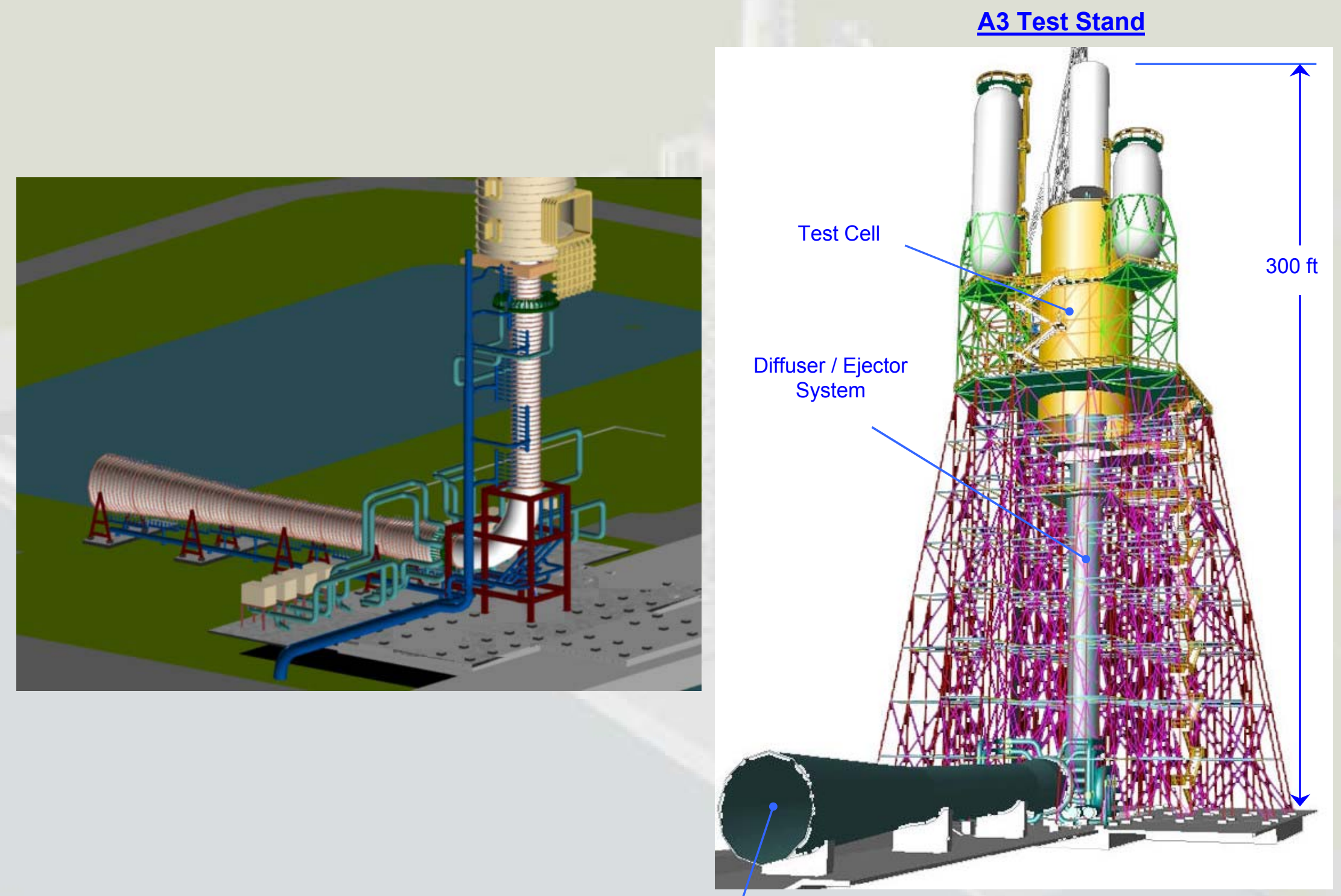

RELEASED - Printed documents may be obsolete; validate prior to use.h Discharge to 


\section{A-3 Test Stand 3-D Layout}

\section{Foundation}

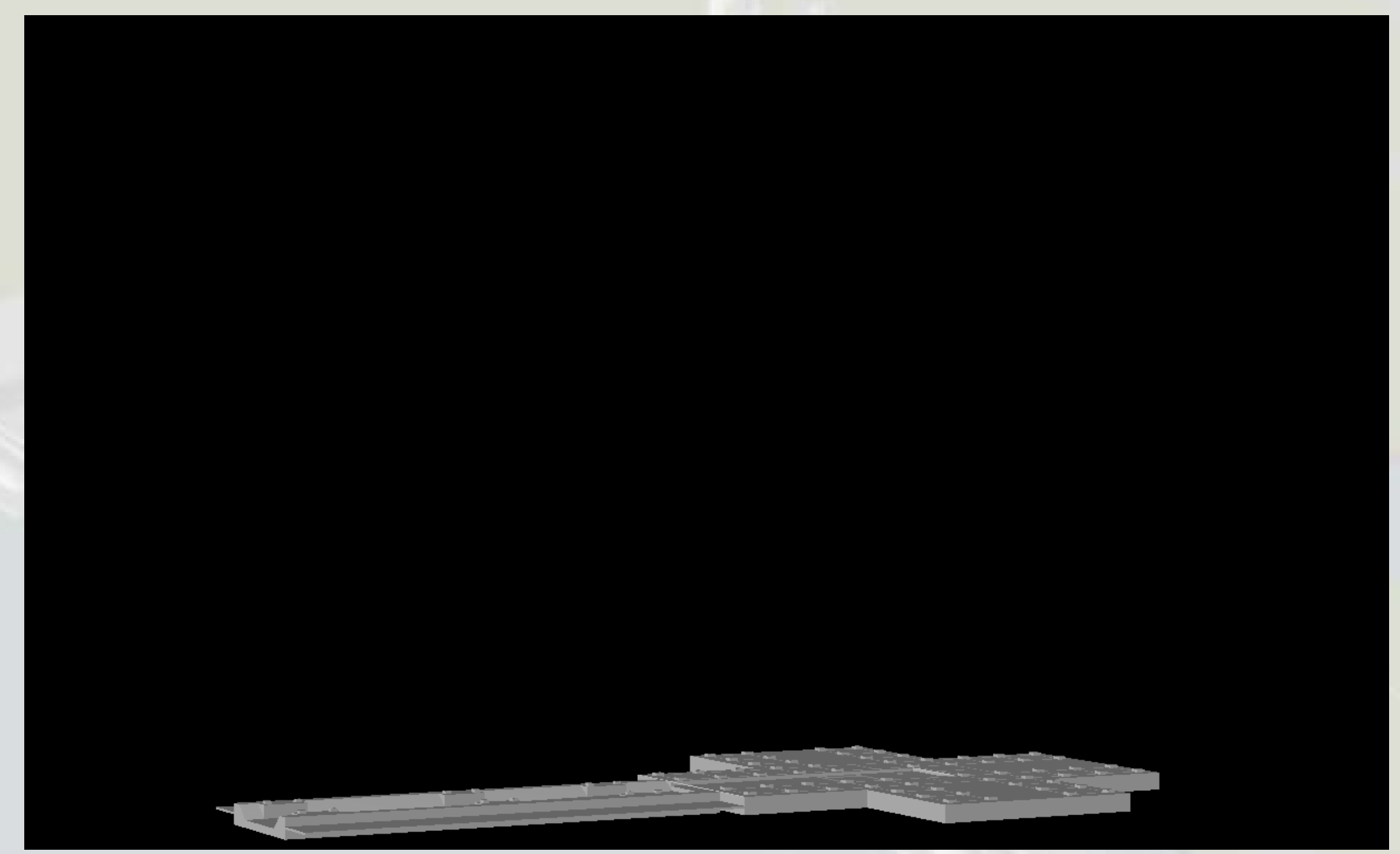




\section{A-3 Test Stand 3-D Layout \\ Diffuser and Exhaust Train}

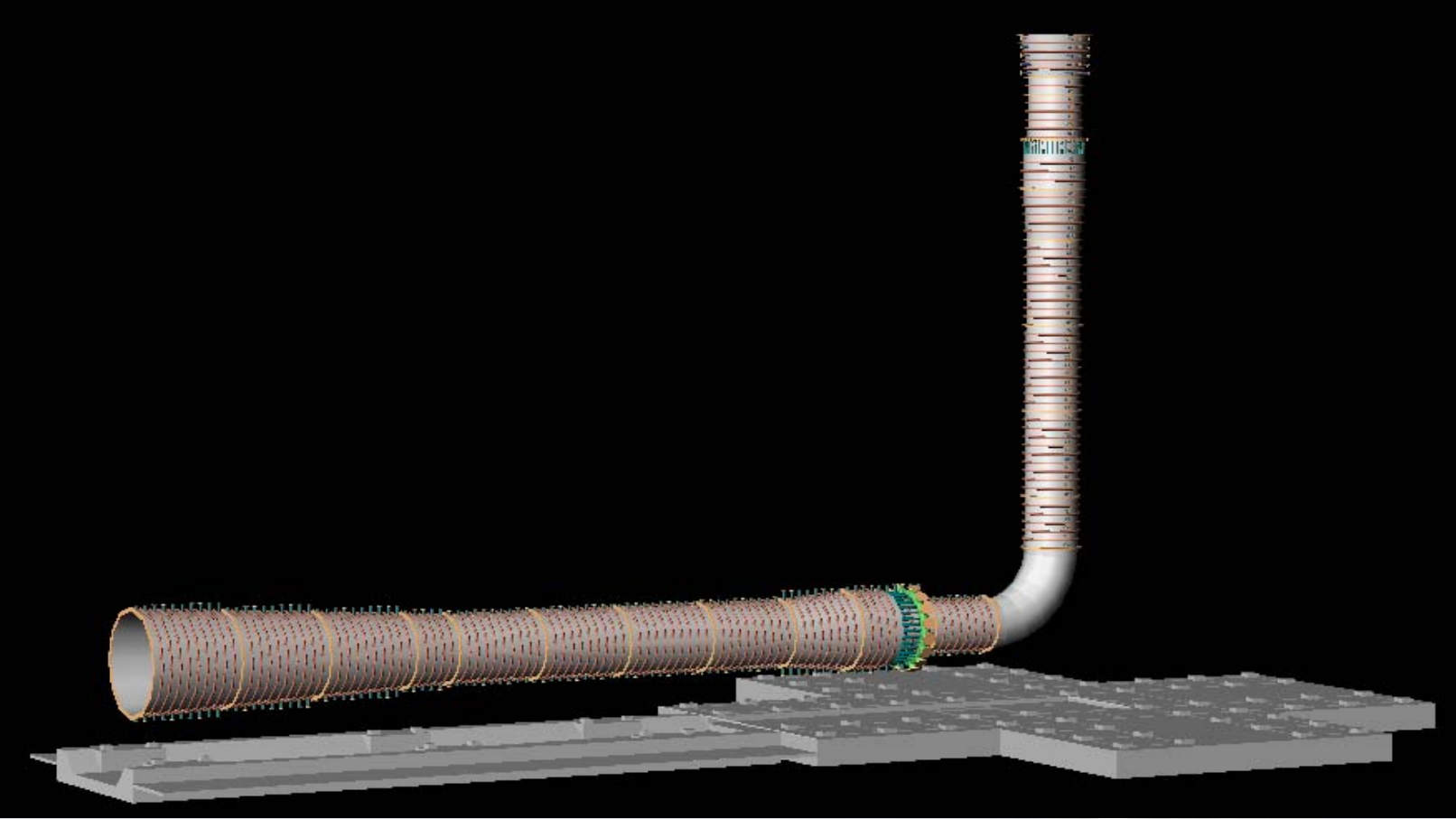




\section{A-3 Test Stand 3-D Layout $1^{\text {st }}$ Stage Steam Ejector}

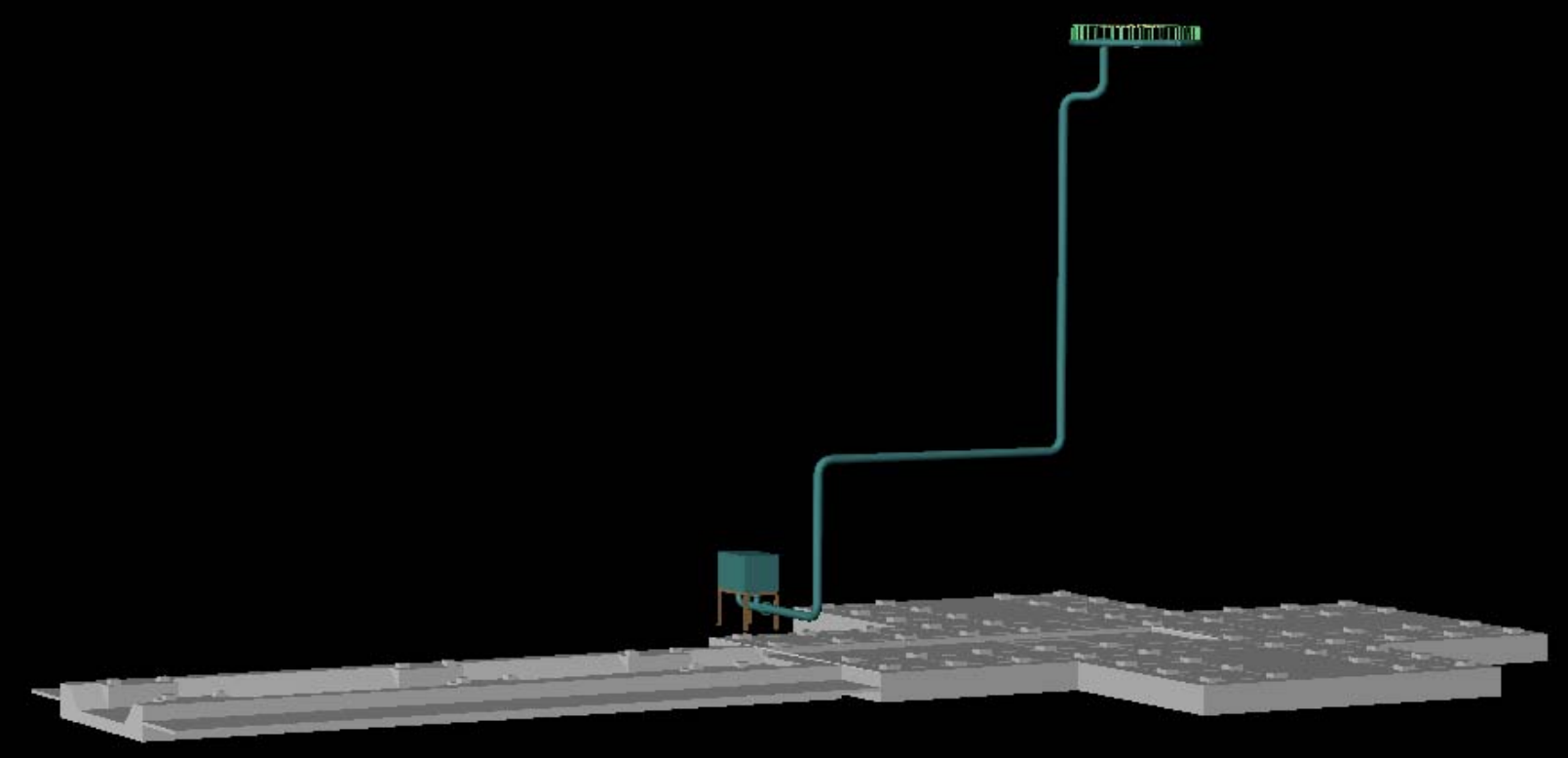




\section{A-3 Test Stand 3-D Layout $2^{\text {nd }}$ Stage Steam Ejector}

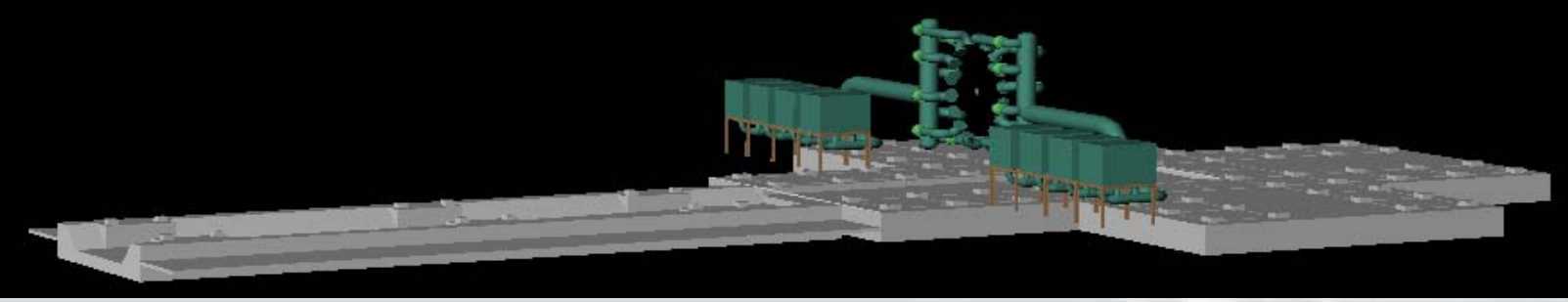




\section{A-3 Test Stand 3-D Layout Cooling Water}

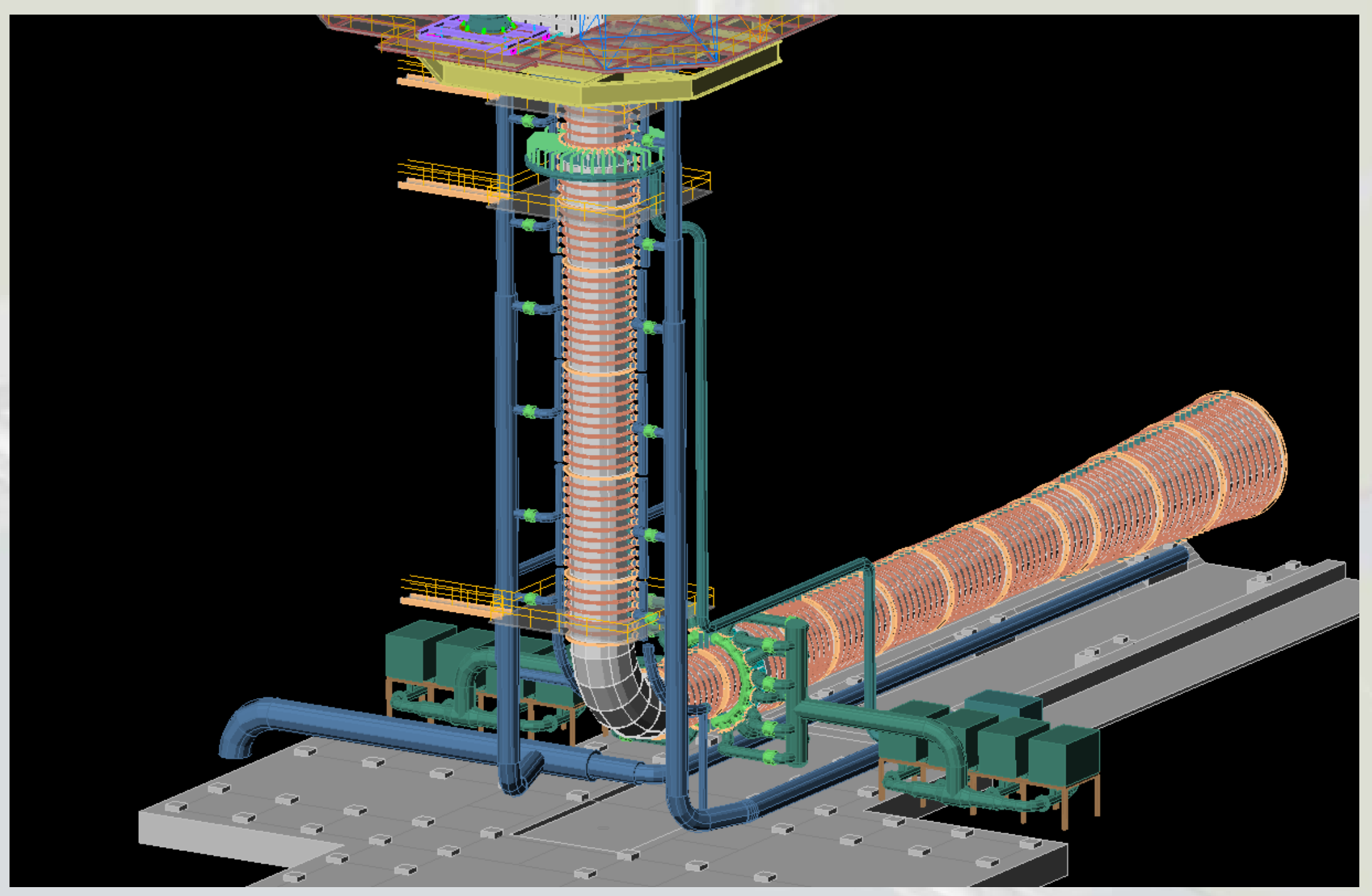




\section{A-3 Test Stand 3-D Layout}

\section{Diffuser, Cooling Water and Ejectors}

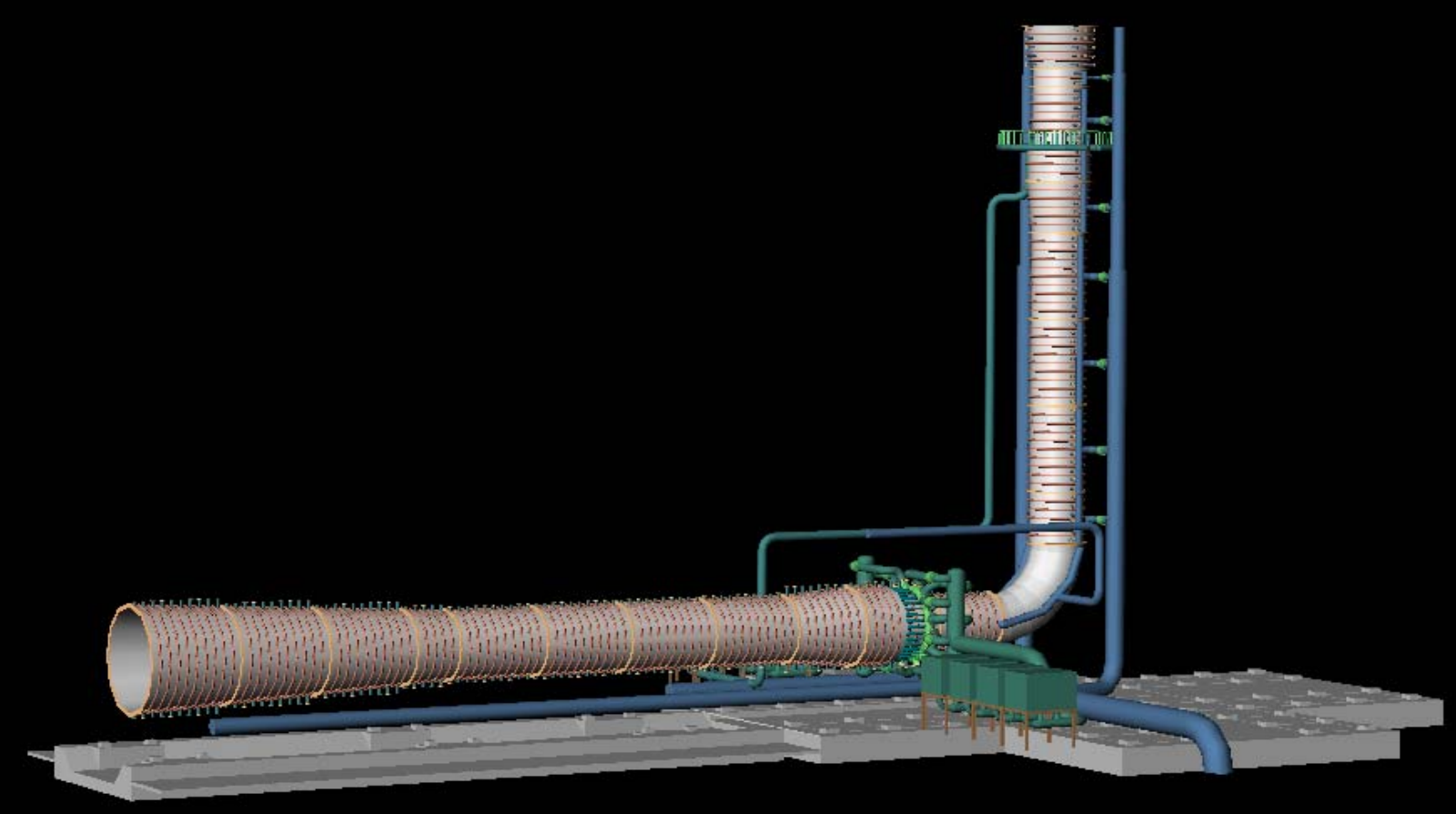




\section{A-3 Test Stand 3-D Layout Access Stairs and Platforms}

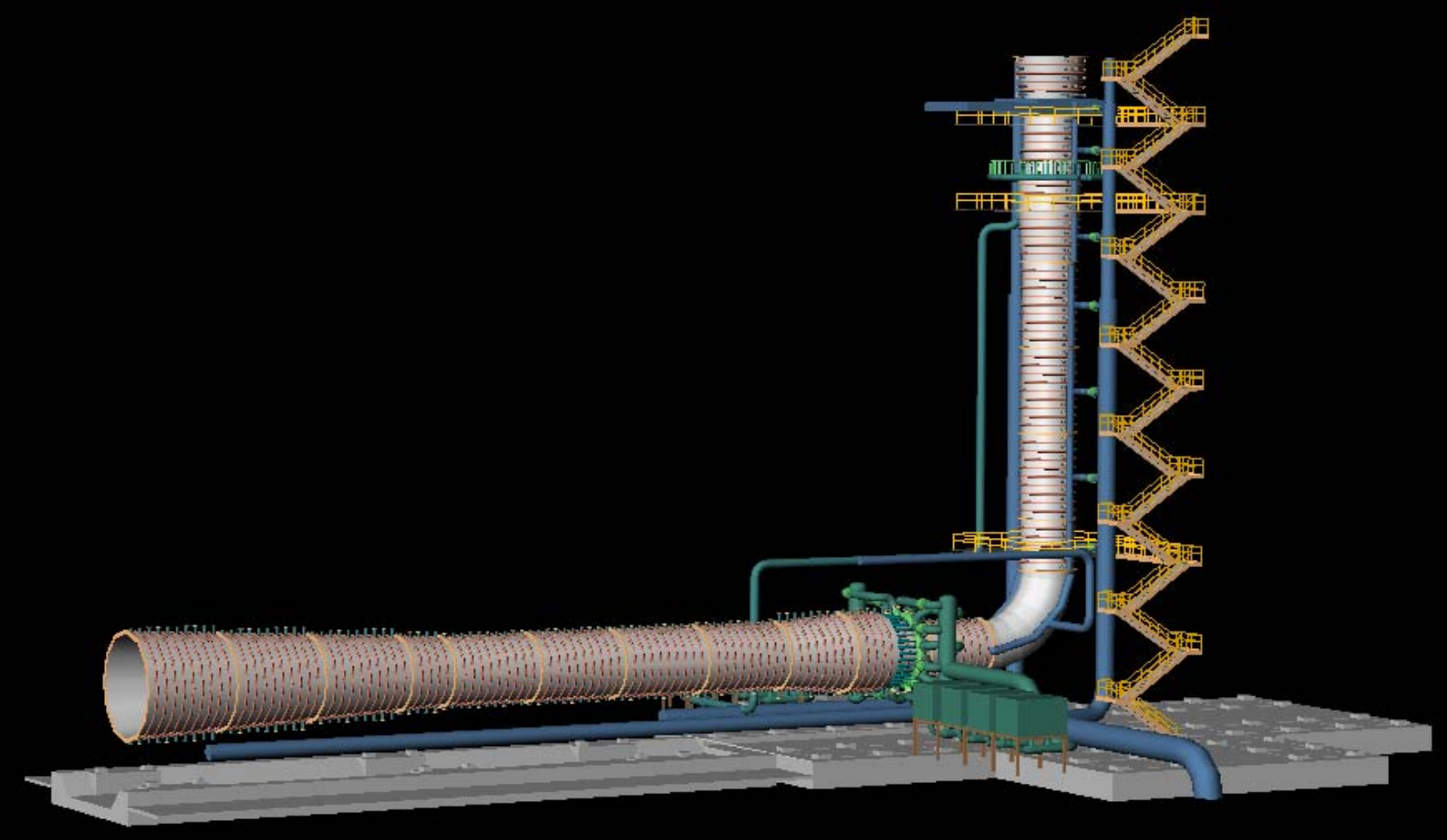




\section{A-3 Test Stand 3-D Layout Elevator}

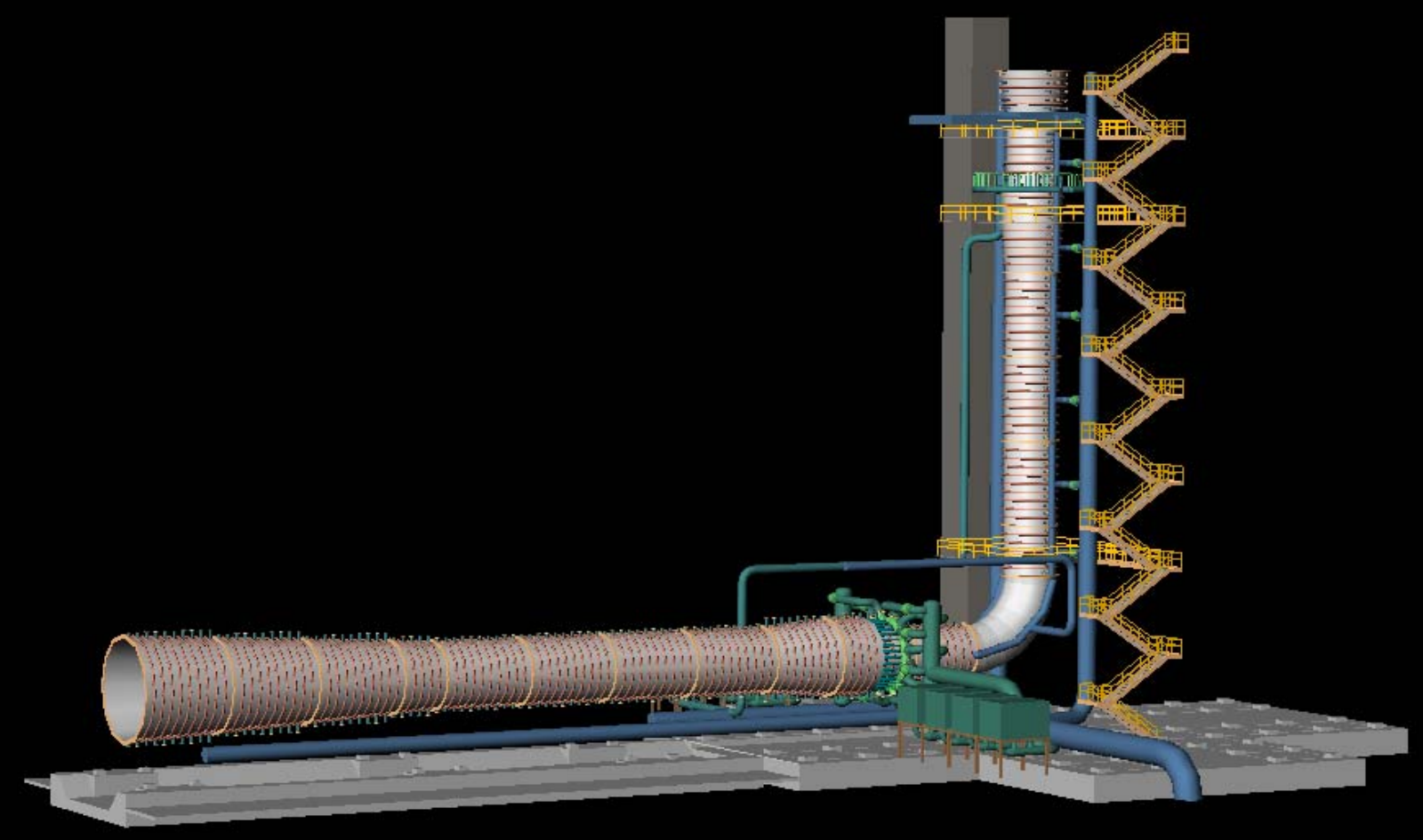




\section{A-3 Test Stand 3-D Layout}

Engine Work Deck

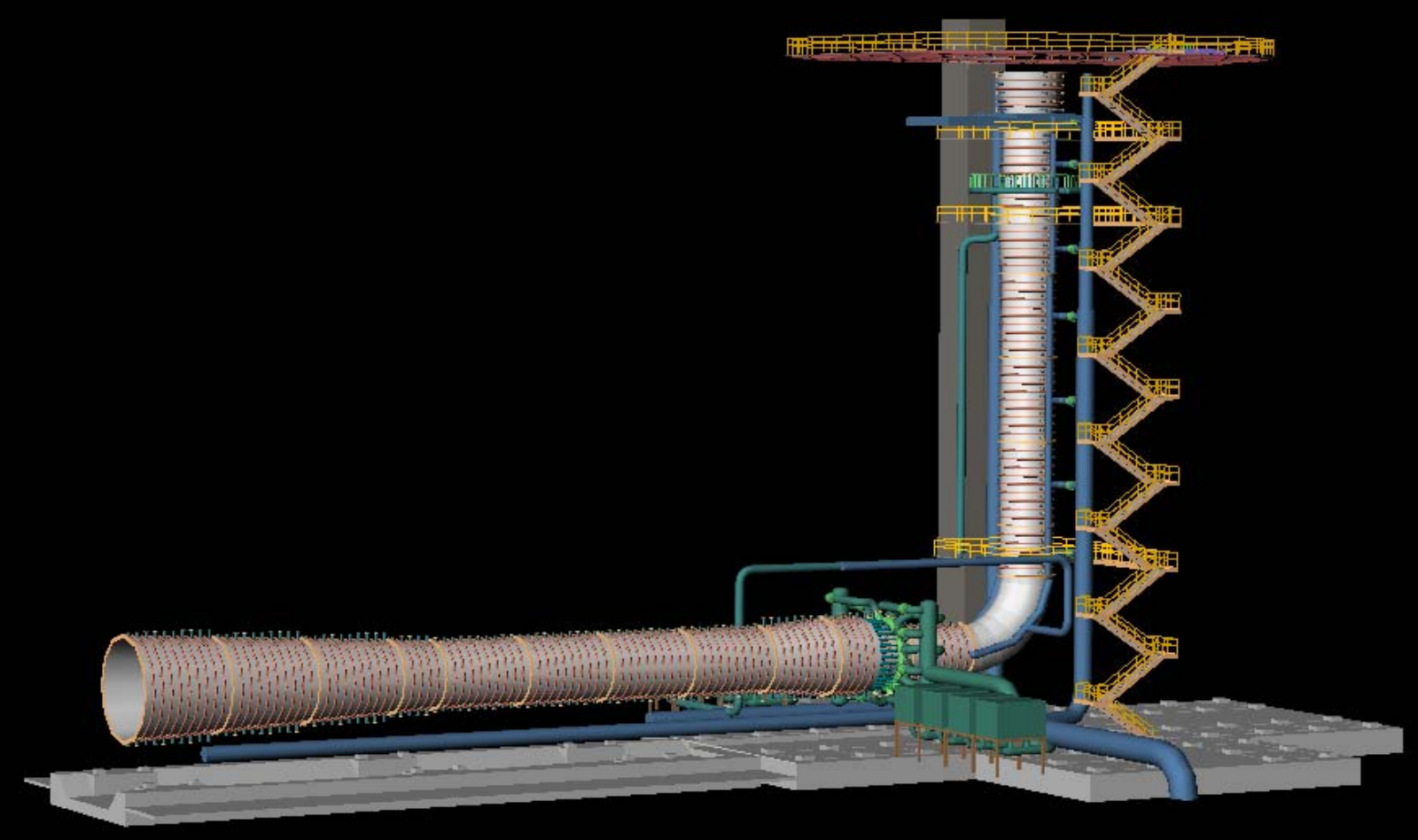




\section{A-3 Test Stand 3-D Layout Structural System}

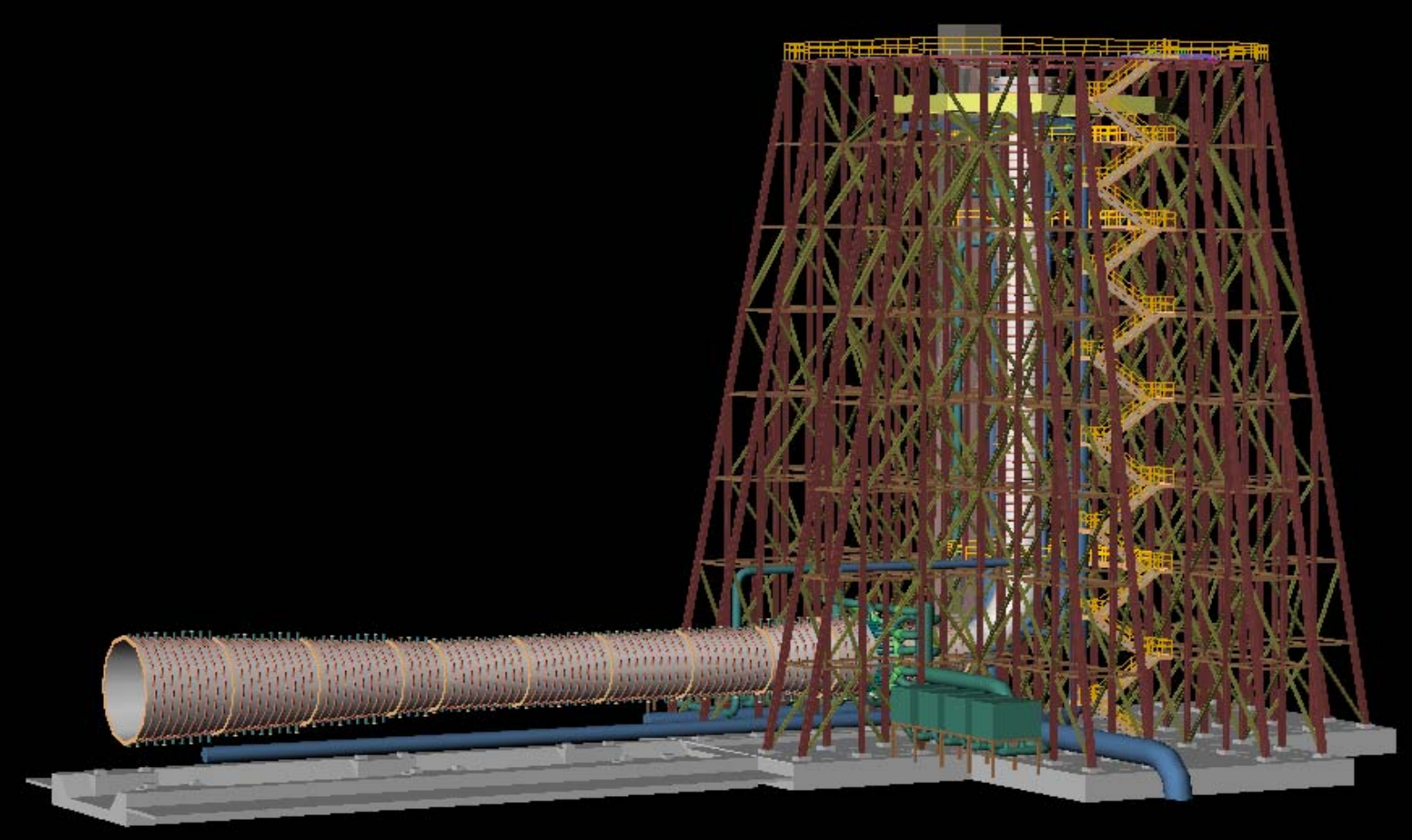




\section{A-3 Test Stand 3-D Layout Test Cell and Thrust Takeout}

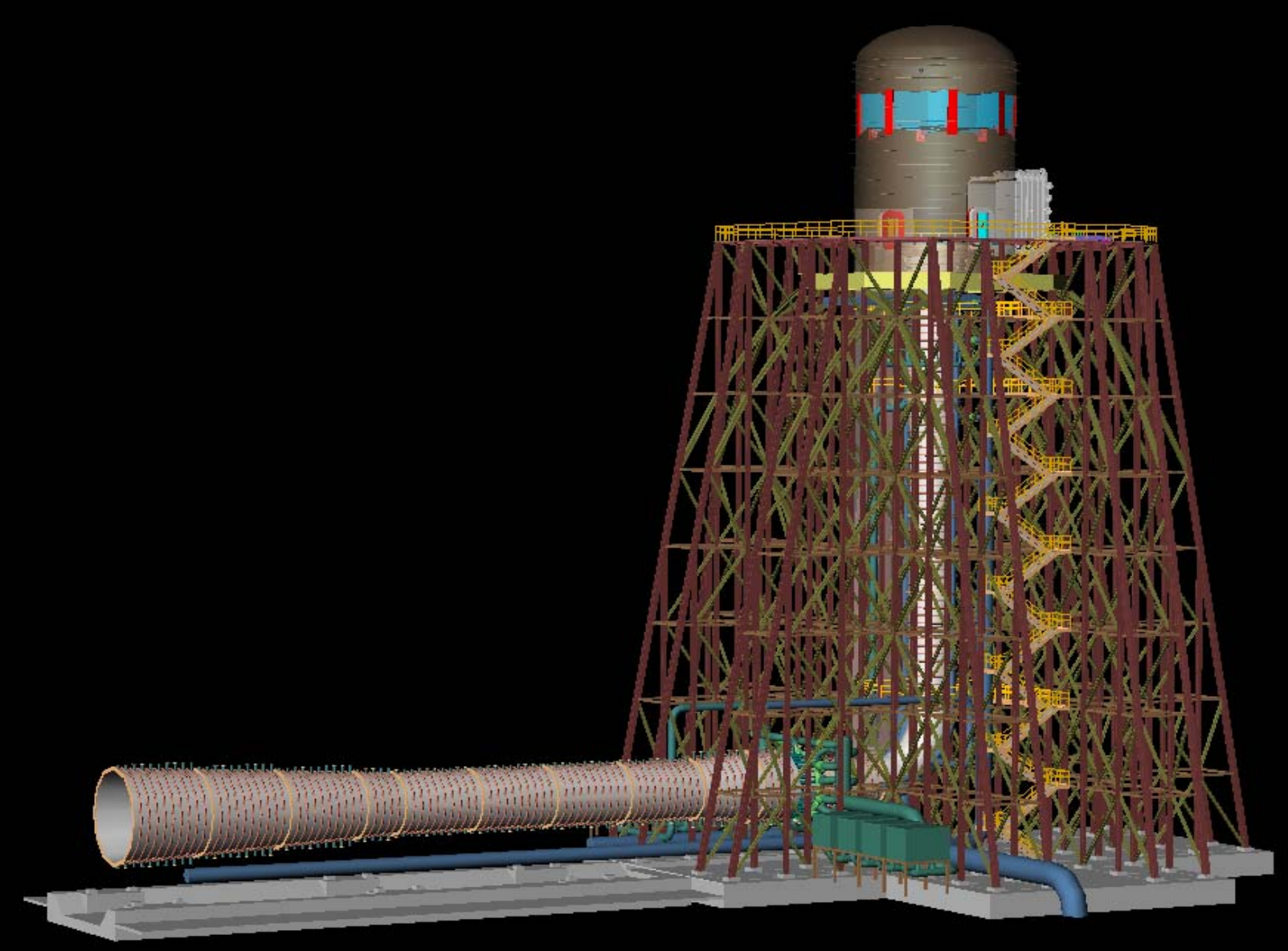




\section{A-3 Test Stand 3-D Layout \\ Test Cell and Thrust Takeout}

- $\quad 80,000$ gallon LH tank

- $\quad 35,000$ gallon LOX tank

- Volume includes:

- $10 \%$ ullage

- Test duration: 350 seconds

- $\quad 10 \%$ remaining in heel of run tank

- Volume included:

- Chill down of run line

- Fill run line

- Chill test article

- $\quad$ Tank will be topped off from the barigs after chilling and filling

- $\quad$ Preferred option because of single tank and limitation of tank height

- Additional Run Time will accompliged/frough in-test propellant transfer.

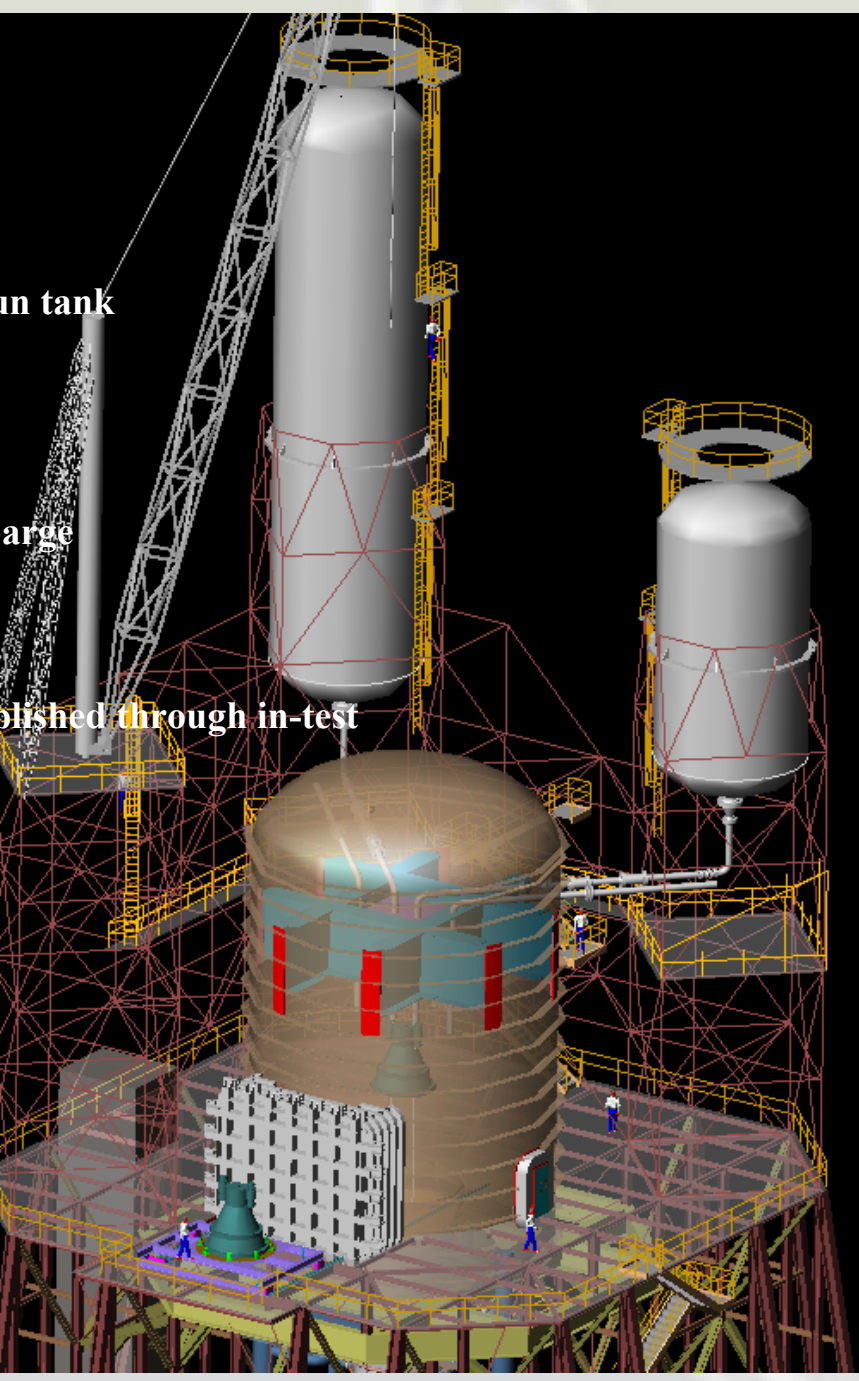




\section{A-3 Test Stand 3-D Layout}

\section{Engine Deck and Superstructure}

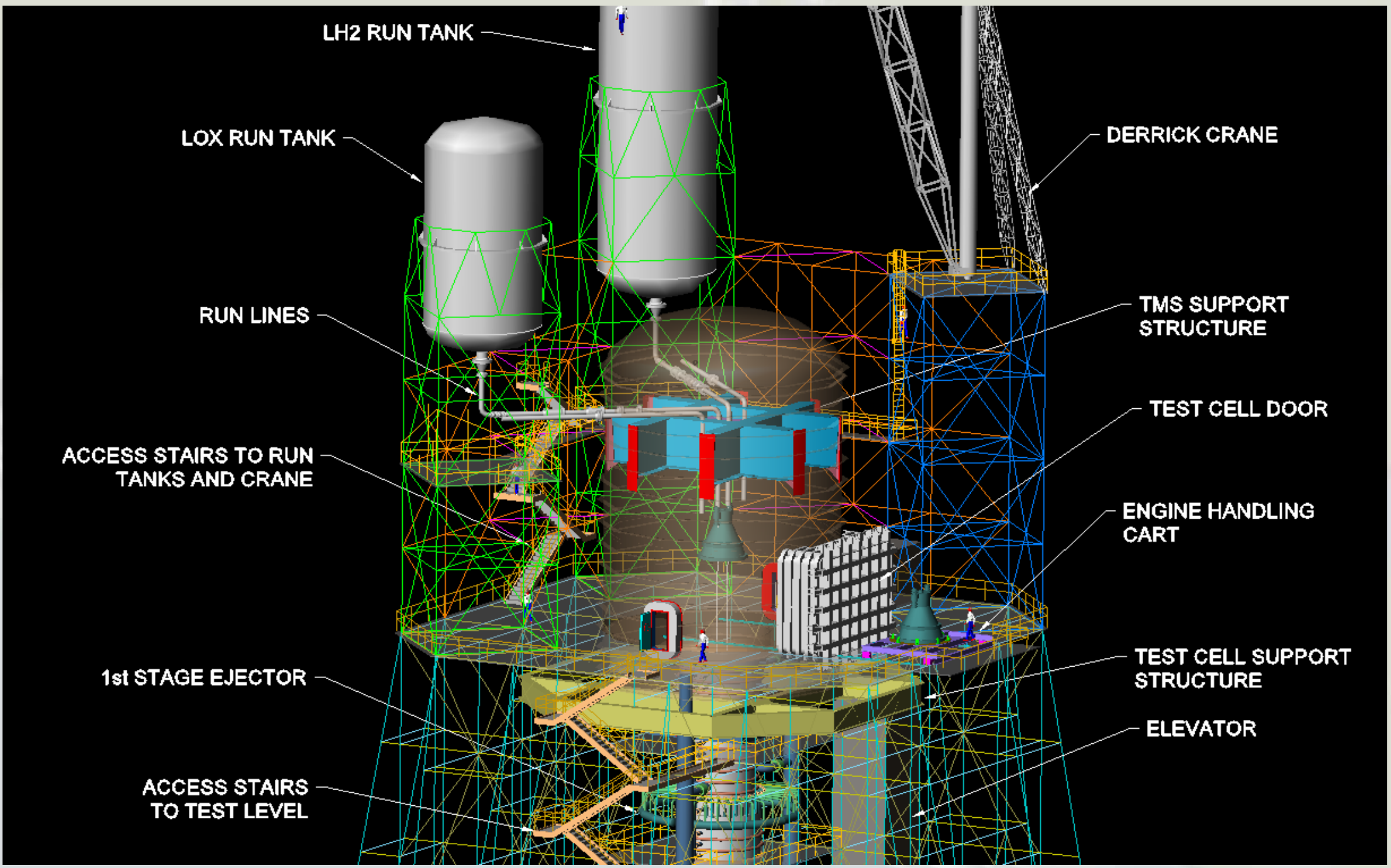




\section{A-3 Test Stand 3-D Layout \\ Structure and Altitude Support Systems}

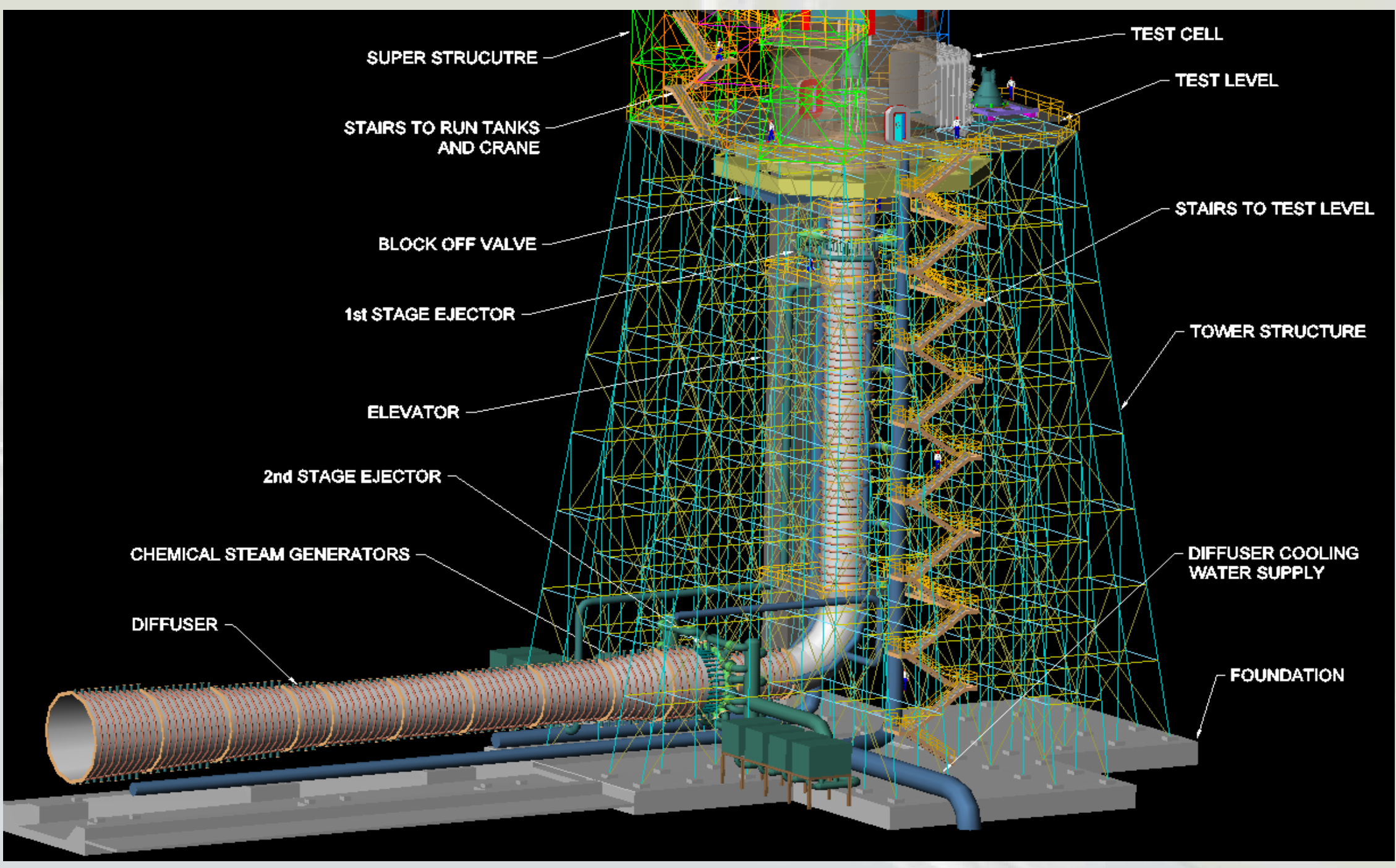

RELEASED - Printed documents may be obsolete; validate prior to use. 


\section{Steam System}

- A-3 Steam System Schematic Diagram

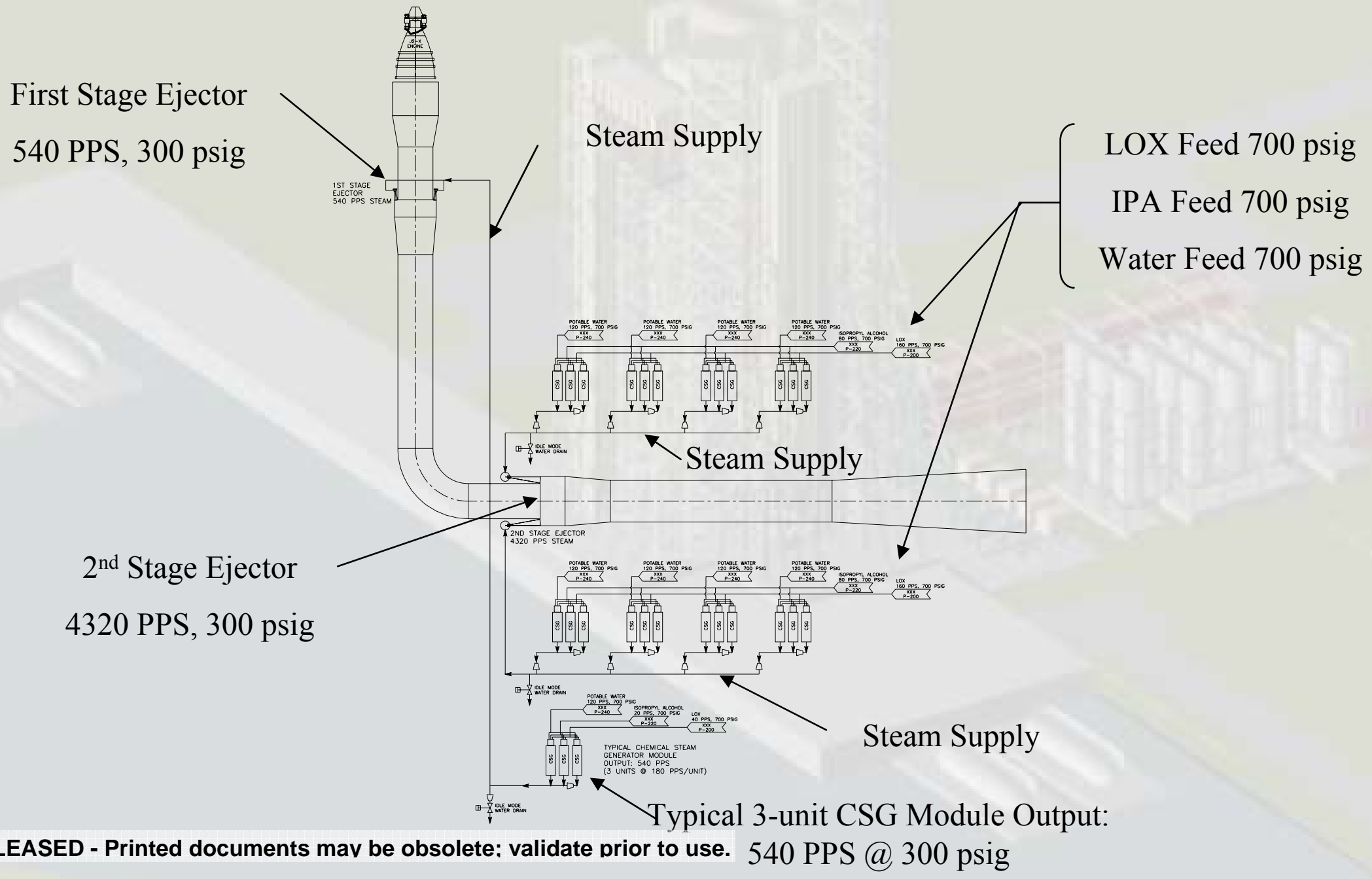




\section{Chemical Steam Generators}
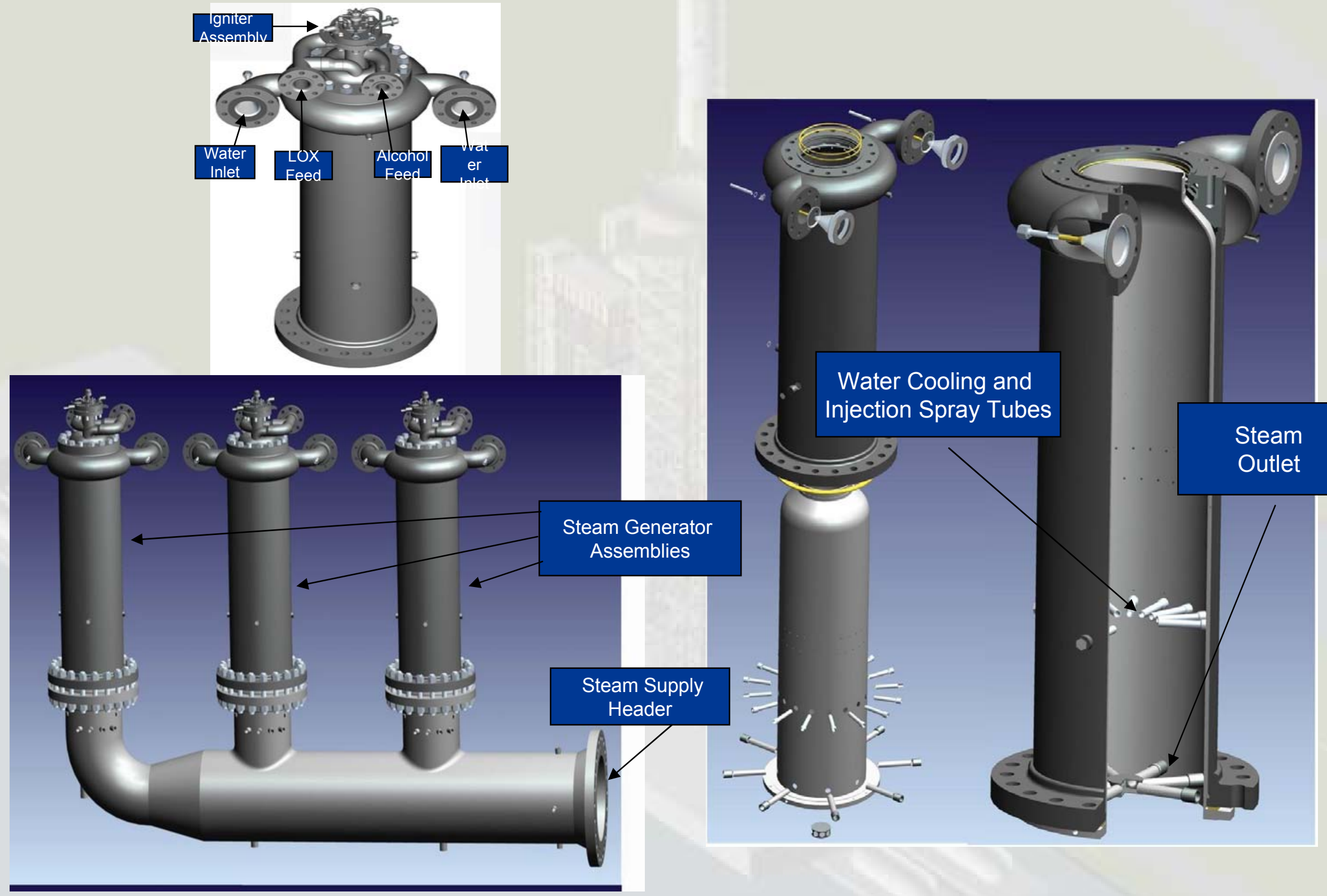

Injection Spray Tubes 


\section{Steam Generation System}

AX Steam System Propellant Feed/Storage requirements

LOX: 89,609 gallons

- IPA: 62,478 gallons

H2O: 277,670 gallons

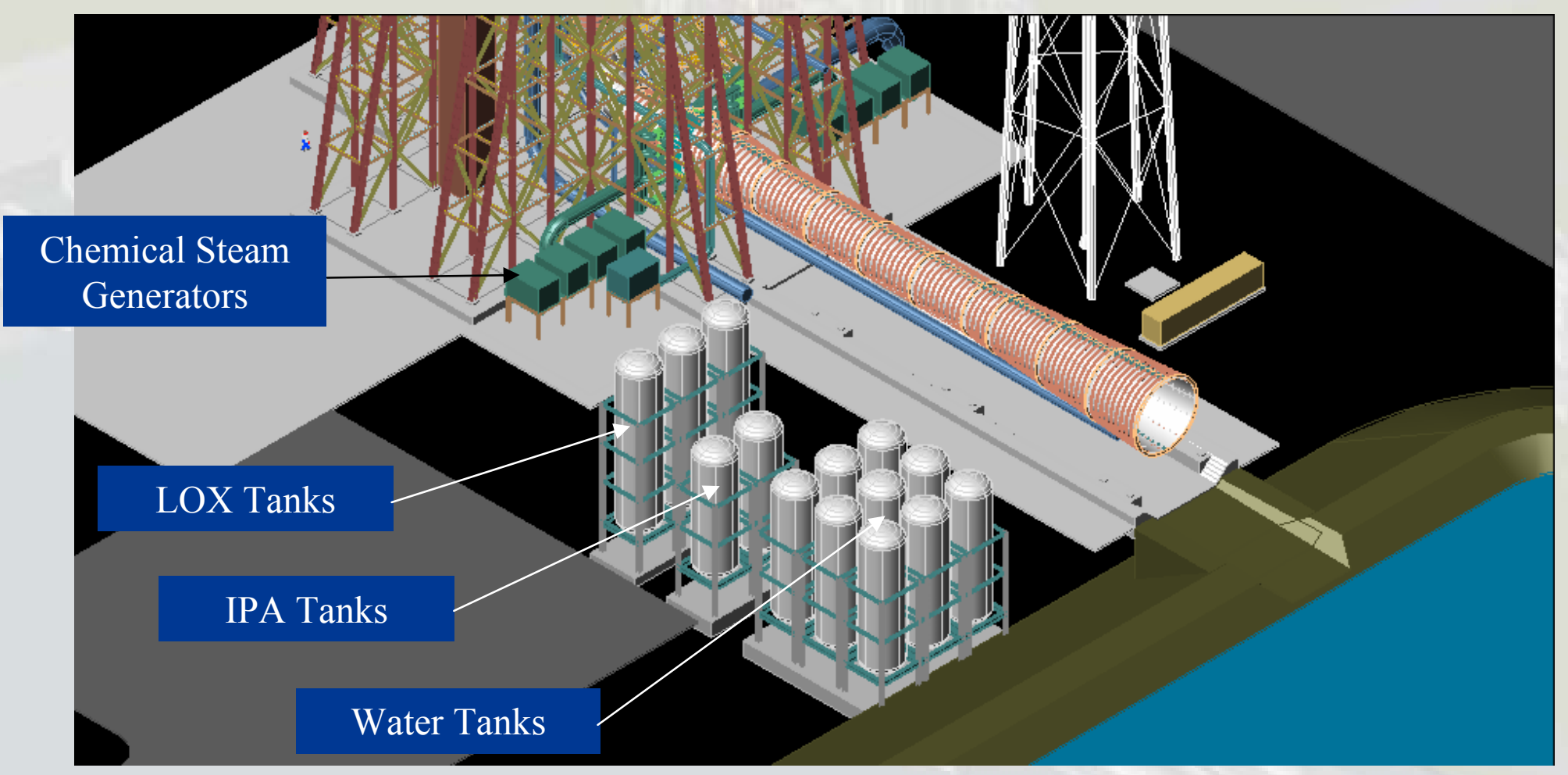




\section{Steam Ejectors}

$1^{\text {st }}$ Stage Ejector: Conical Nozzles, 460 PPS

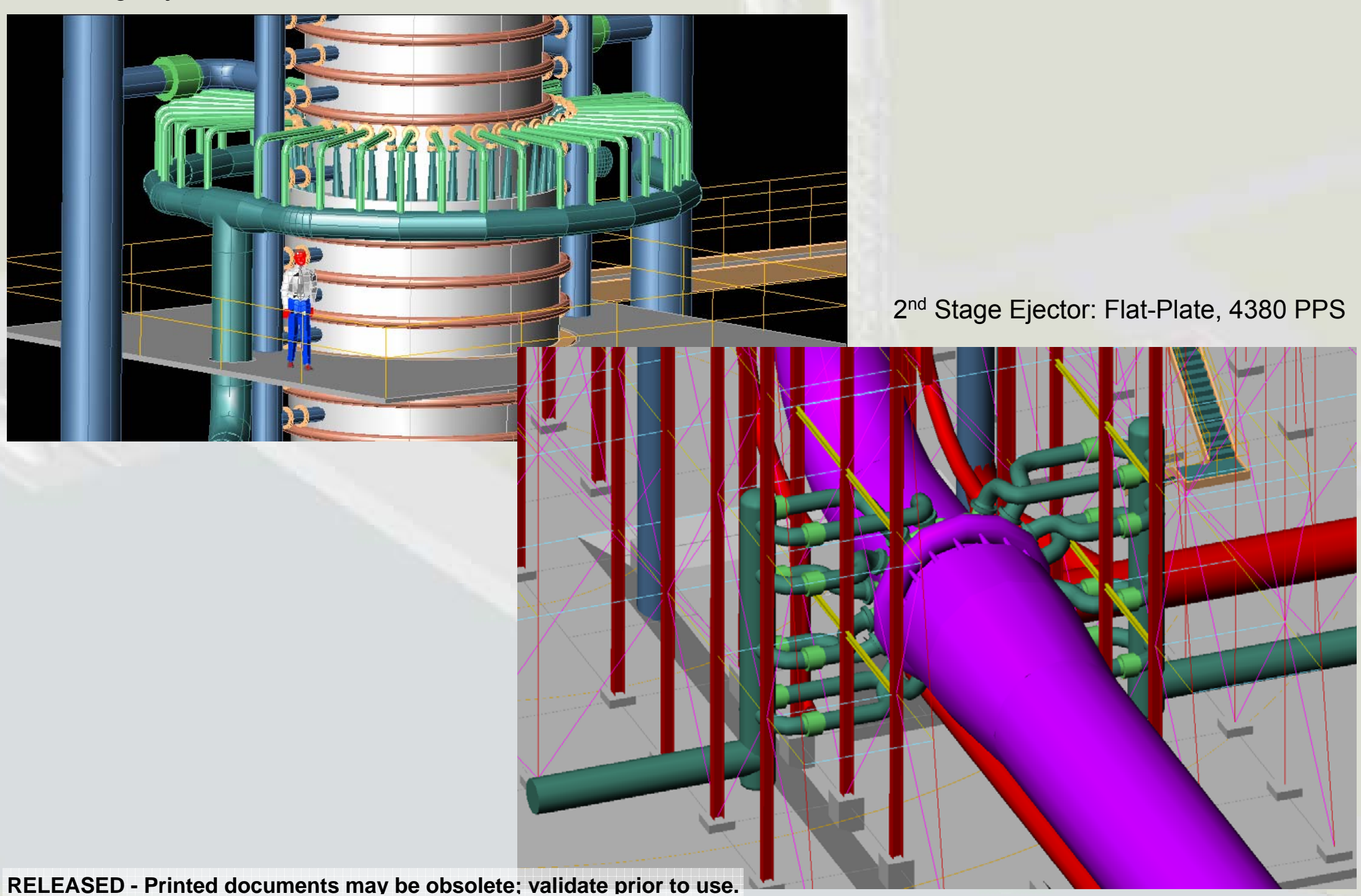




\section{Sliding Gate Valve}

- Adverse pressure waves, differential pressures across the nozzle, and steam on hot engine components can be avoided with a valve in the diffuser upstream of the $1^{\text {st }}$ stage ejector.

- A sliding gate valve in the diffuser would be closed after test to prevent shutdown effects from reaching the engine.

- This valve would negate the option of using a high flow rate $\mathrm{GN}$ purge in the test cell. 


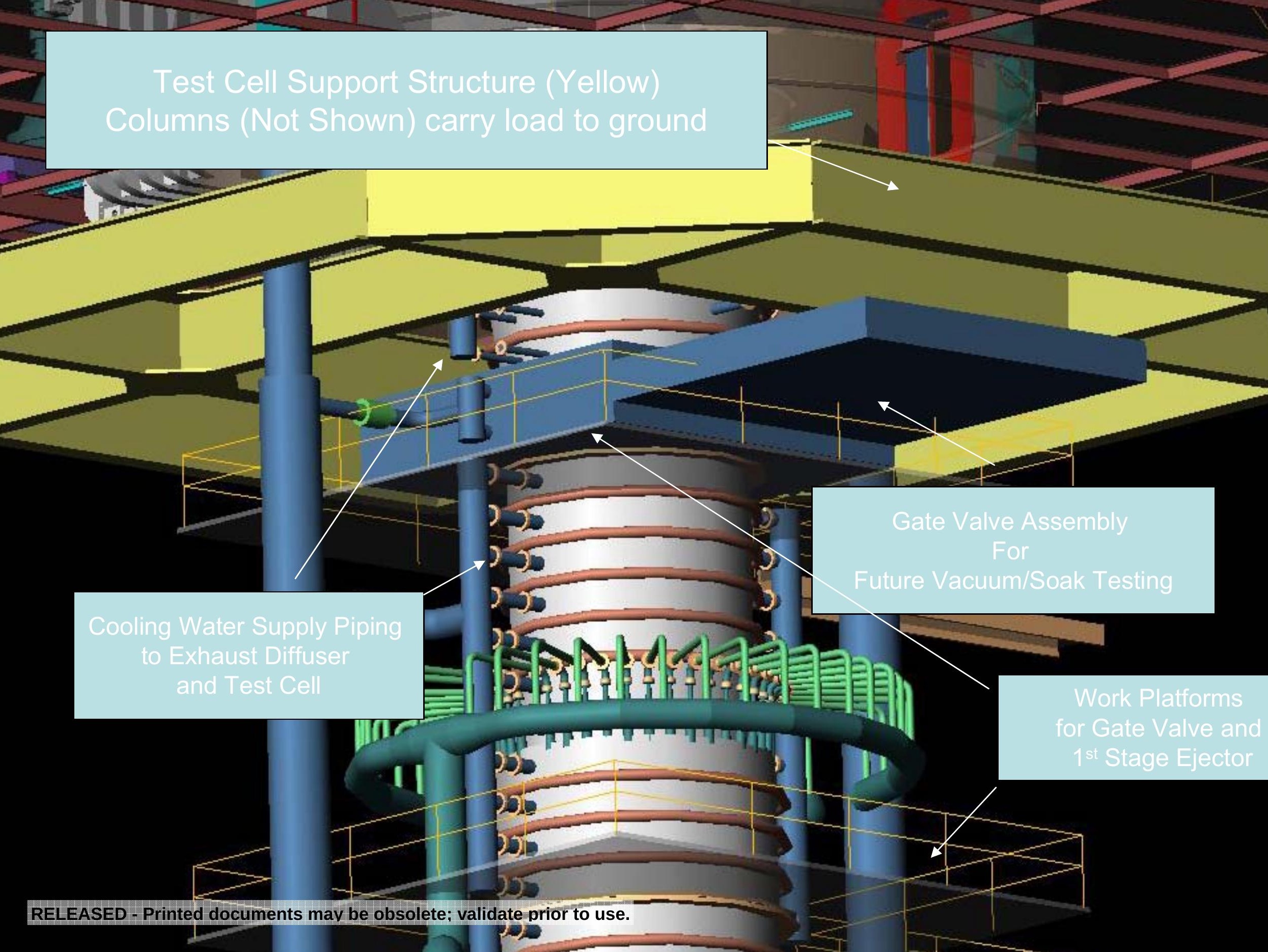




\section{Test Cell Configuration}

- 40' diameter cylindrical shell

- Ellipsoidal head

- Inverted conical floor

- Raised floor with embedded cart rails

- Main hatch: Vertical translation of a flat door

- Cylindrical shell used to support the TTOS/TMS

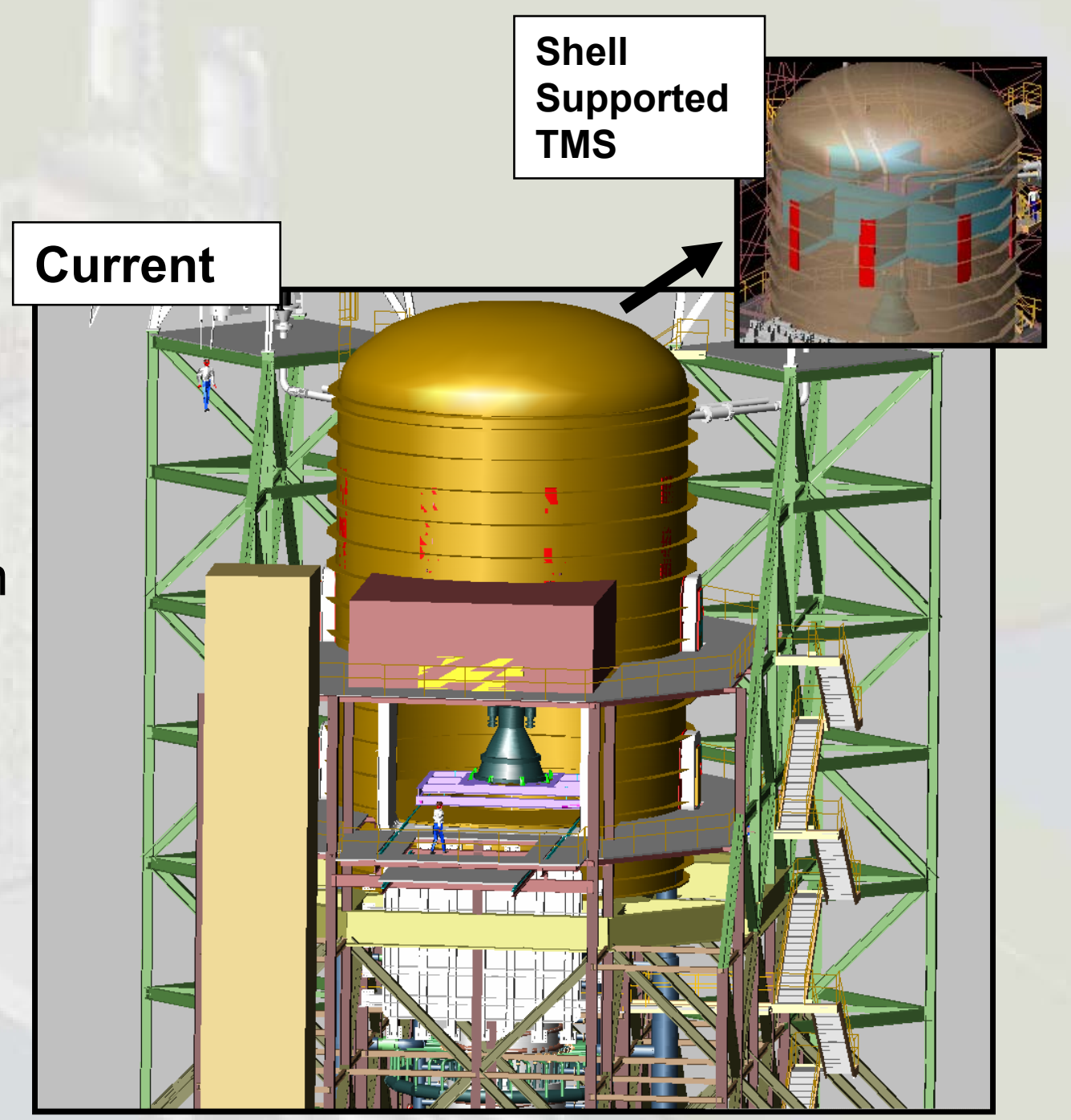




\section{Thrust Measurement System}

- TMS structural assembly consists of the ground frame and live bed.

- Capable of 740K Ibf axial thrust

- TMS Calibration System

- 350K lbf in $\mathrm{y}-$ axis

- 31K lbf in $\mathrm{x}$ - and $\mathrm{z}$ - axes

- TMS Measurement System

- Total Measurement Uncertainty:

$0.25 \%$ along vertical axis

$0.85 \%$ along lateral axis

- TMS Hydraulic Pump Skid located near the Test Cell under a covered area.

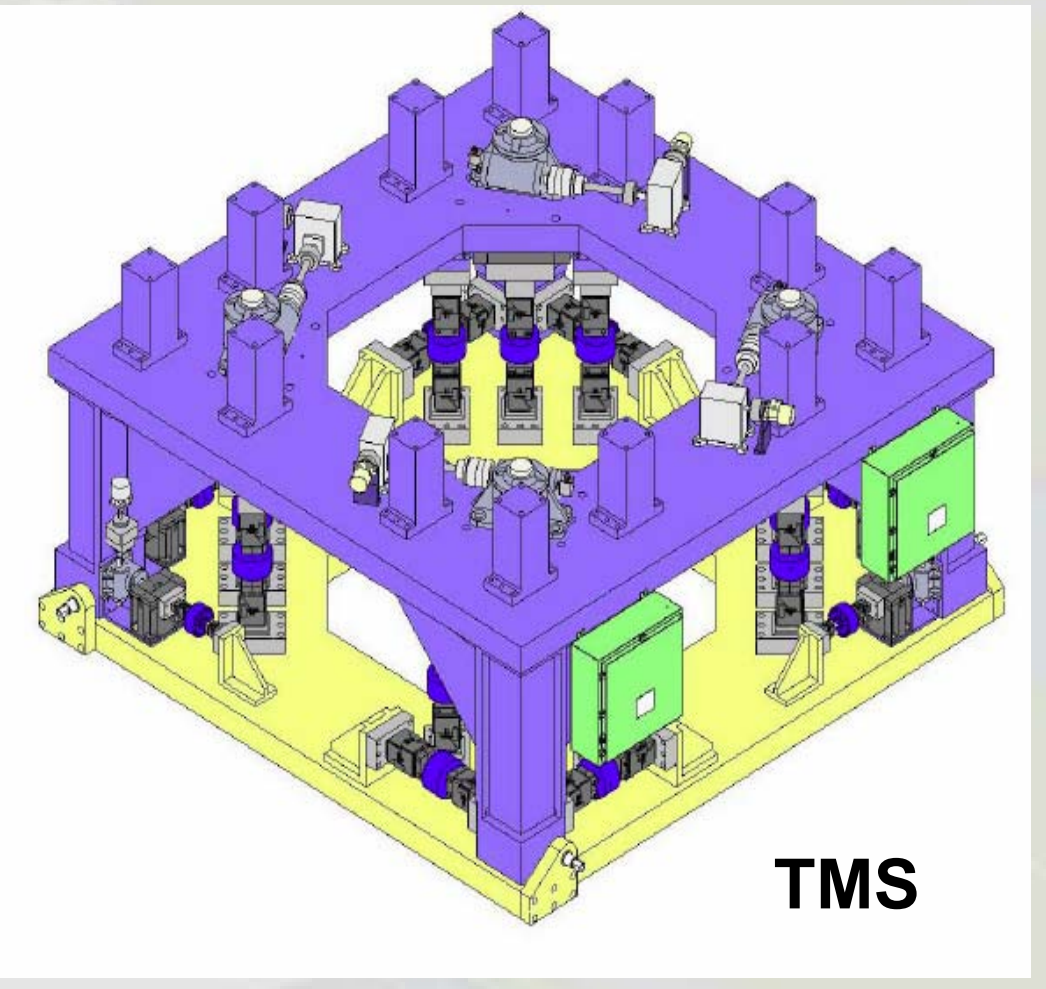




\section{Thrust Takeout Structure}

- Upper surface of the TMS ground frame is supported by the TTOS.

- TTOS designed for $600 \mathrm{~K} \mathrm{lbf}$ static vertical thrust / 900K lbf dynamic vertical thrust.

- Stiffness of the TTOS shall be, as a minimum, .005 " deflection at 600,000 lbs vertical \& $.005 "$ deflection at $125,000 \mathrm{lbs}$ lateral.

- Holes for attaching TMS structural assembly to TTOS drilled per TMS bolt hole template (TMS Vendor).

- TMS/TTOS installation requires simultaneous lift after attaching both pieces together.

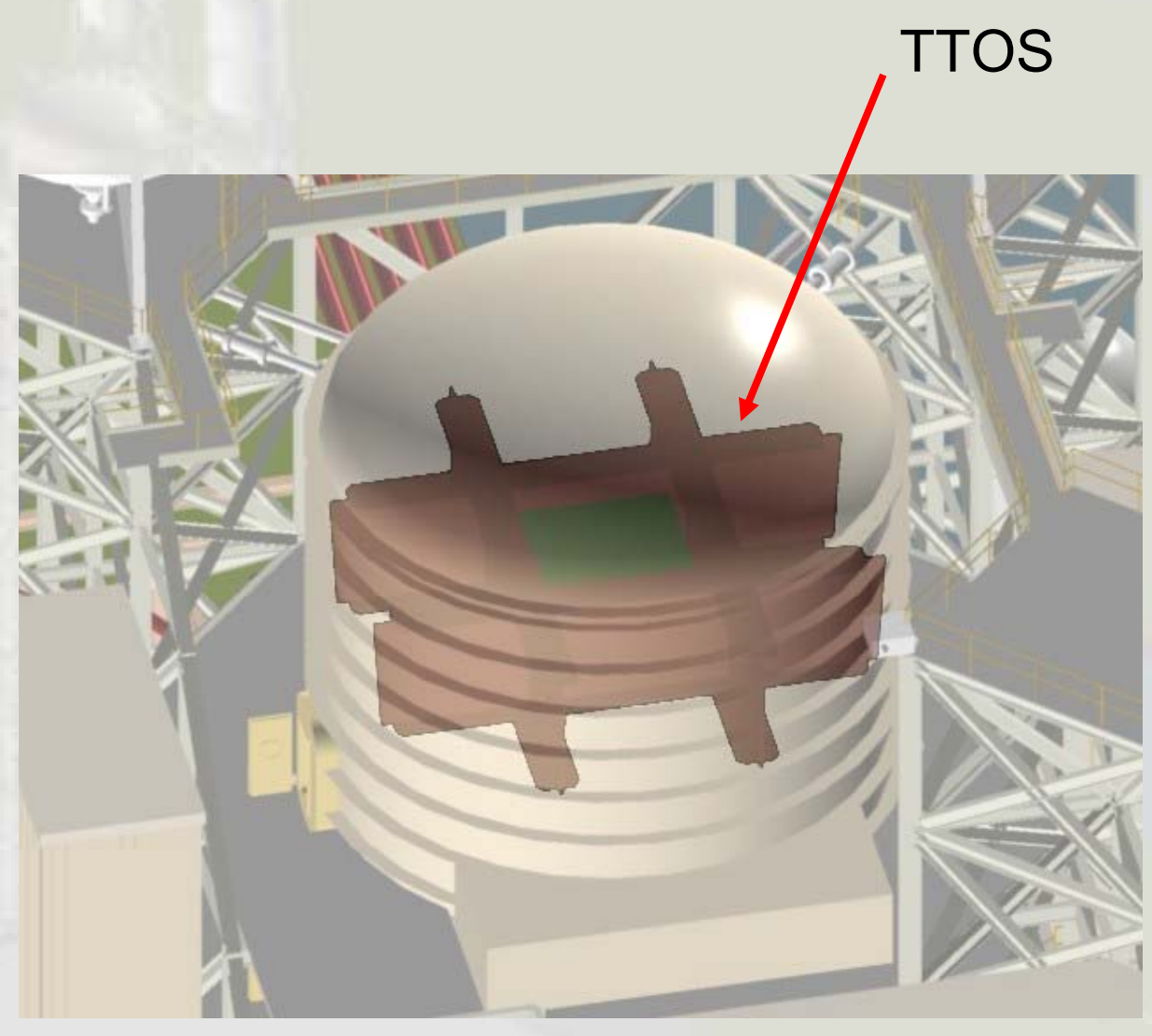

- Bolted to Test Cell Wall: Remove for future stage testing. 


\section{Diffuser Capture Duct}

- The portion of the diffuser extending inside of the test cell must accommodate pre-test and post-test operations including engine installation.

- The top of the diffuser shall extend above the bottom of the nozzle extension

- This allows a smaller diffuser diameter and lower steam flow requirements than if the diffuser was shorter

- The diffuser must be split into at least two pieces to retract without striking the nozzle extension

- Accommodate high heat flux $170 \mathrm{Btu} / \mathrm{ft}^{\wedge} 2$ $\mathrm{sec}$

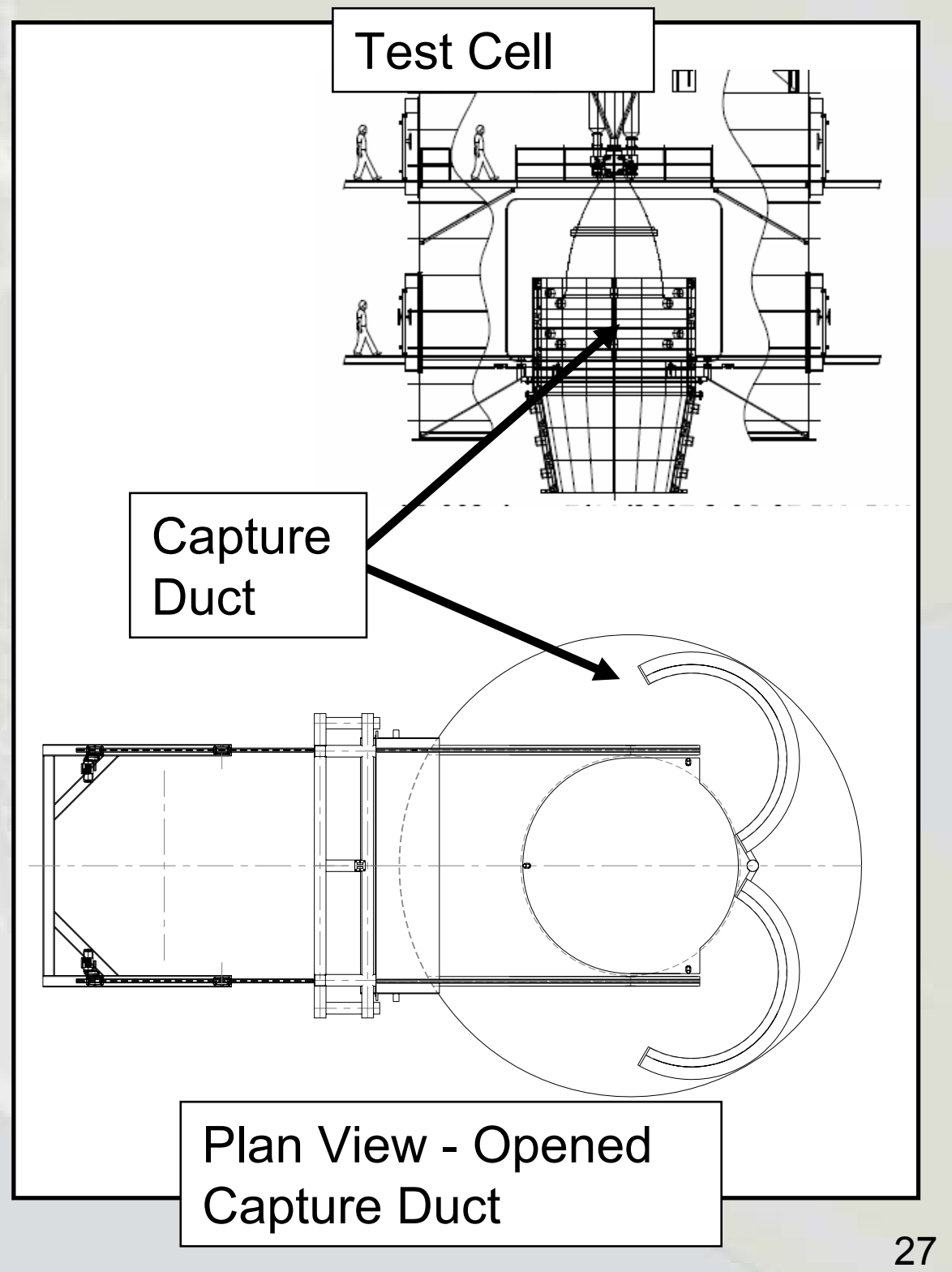




\section{A-3 Risk Mitigation - Subscale Diffuser}

\section{Background}

- A-3 Test Facility risk mitigation are efforts funded via a technical task agreement with MSFC.

- E3 Test Facility Cell 1 for subscale diffuser testing

- E3 Test Facility Cell 2 for DTF-type thruster (STE) characterization tests as well as steam generation activities

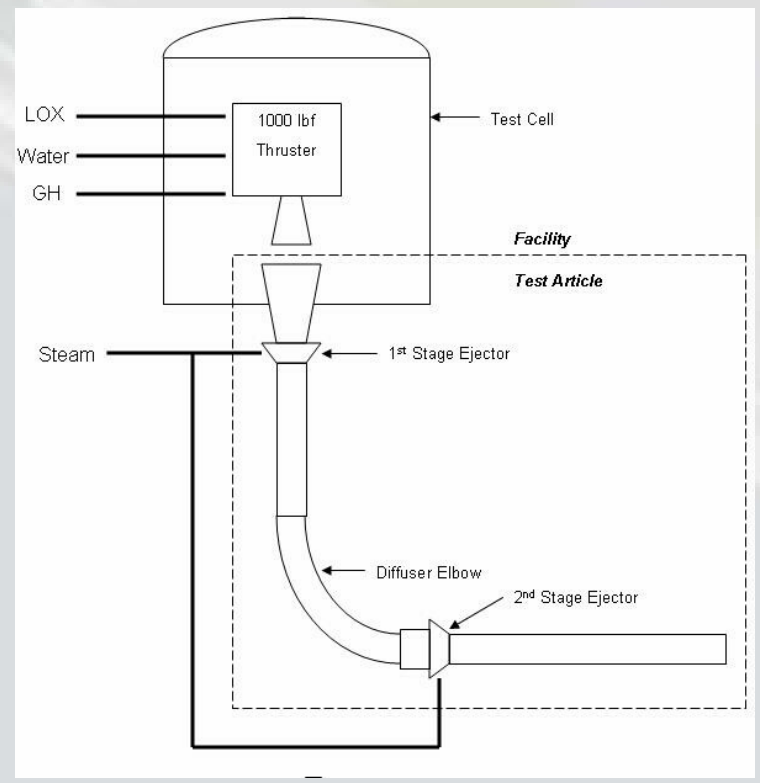

RELEASED - Printed documents may be obsolete; validate prior to use.

\section{Summary of Task Objectives}

Characterize the performance of the subscale diffuser at $\sim 6 \%$ scale and obtain data to support design and analysis efforts for the A-3 test facility.

Phase I - DTF Firing (completed 9/24/2007)

- Successfully ignite the DTF thruster at sea-level and shut down safely (Cell 2)

- Verify repeatability of startup

- Provide performance data regarding the operation

Phase II - Steam Generation (completed 12/12/2007)

- Ignite and characterize steam combustor (modified thruster)

- Integrate steam combustor with water injector system

Phase III - Subscale Diffuser Performance

- Ignite and characterize $\mathrm{J}-2 \mathrm{x}$ simulator (modified thruster) at sea-level $(1 / 8 / 2008)$

- Integrate subscale diffuser and steam generator and characterize $(12 / 13 / 2008)$

- Perform J-2x simulator altitude hotfire tests with subscale diffuser $(1 / 11-18 / 2008)$

- Completed 01/18/08

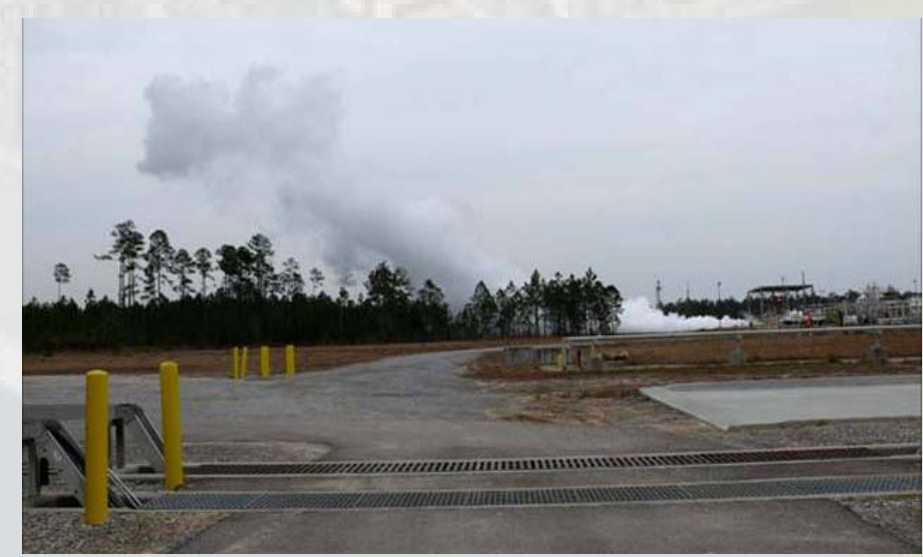




\section{Rocket Diffuser Design}

- Rocket Diffuser (size reduced by using clamshell style capture duct and moving diffuser inlet lip above the NEP

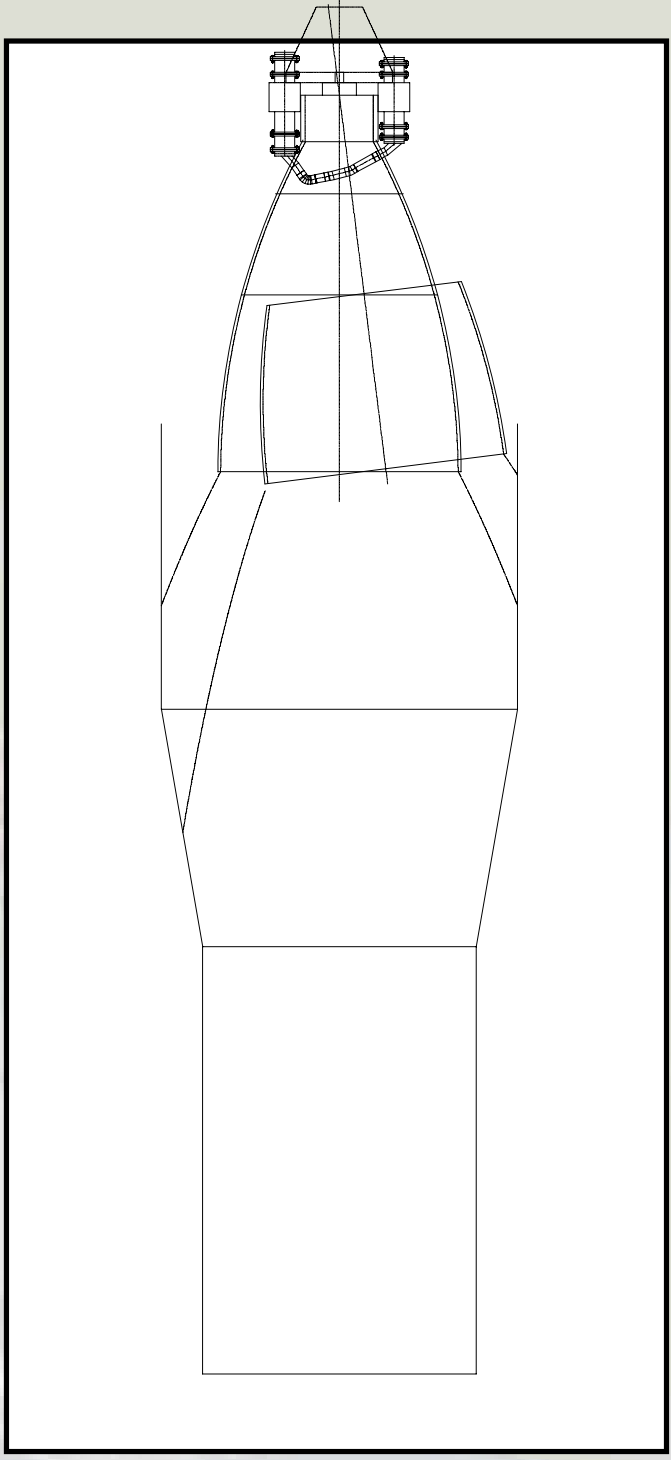




\section{Summary}

- Altitude Testing of the J2-X engine at 100,000 feet (start capability)

- Chemical Steam Generation for providing vacuum

- Project Started Mar' 07

- Test Stand Activation around Late 2010

- J-2X Testing around early 2011 